\title{
The Comparative Study on the Cavalry of the Liao Dynasty and the Song Dynasty
}

\author{
Cheng XING ${ }^{1, *}$ \\ ${ }^{1}$ Northeastern University, Shenzhen, Guangdong Province 518038, China
${ }^{*}$ Corresponding author. Email: 20175669@stu.neu.edu.cn
}

\begin{abstract}
The war between the Liao Dynasty and the Song Dynasty symbolized a peak of the history of the Chinese heavy cavalry. At this time, because of the development of the foundry technique, both the weapons and the armors of the cavalry were of better quality than any other Chinese dynasties before. In order to get the advantage in the arms race, both Liao and Song devoted lots of resources to the army, especially to the construction of cavalry. The commanders tried every kind of new equipment on their cavalry. We can even say that the Chinese cavalry had the best equipment in the world in the $10^{\text {th }}$ century. However, because of misleading propaganda, some incorrect stereotypes have taken root. Firstly, a large number of people don't know whether heavy cavalry exists in the Song Dynasty, resulting the stereotype that the Song Dynasty lacks horses. Moreover, most people thought that the cavalry of the Song Dynasty was weak while the Khitan (The governing nationality of the Liao Dynasty, originated in the northeastern part of China. The name Khitan first appeared in Wei Shu [1]) cavalry was fighting, since they are misled by the view that Song was poor in the military. However, these points of view did not jibe with the facts. In history, the Song Dynasty owns not only heavy cavalry but also good military exploits. The cavalry of the Liao dynasty didn't get tremendous advantages when facing their peers of the Song Dynasty. This paper will conduct a comparative study on the cavalry of these two dynasties and break the stereotype.
\end{abstract}

Keywords: The Liao Dynasty, The Song Dynasty, Cavalry

\section{INTRODUCTION}

The study of the military history of the Song Dynasty is usually influenced by stereotypes. In the research of the military history of the Song Dynasty, this phenomenon is even more common. Whether in the Western or Eastern, most historians think that the Song Dynasty was powerful in the economy but weak in the military. According to a famous historian Qianmu's Outline of Chinese History, the Song Dynasty was even poor in both military and economy fields [2]. However, based on several researches, it was clear that the military force, especially the Song Dynasty's cavalry, shouldn't be just understood as weak. At different times, the performance of the cavalry of the Song dynasty was different. As for the cavalry of the Liao Dynasty, as known as Khitans, their images were not totally the same as the traditional cognition. At least they were not the same as the Huns.
However, comparing with the problems of concept, the barrier between the research of Chinese military history and Western military history is the thing that really needed attention. We take some ancient weapons as an example. Western scholars call each kind of special Chinese spears 'halberd', even they had totally different uses. In Chinese, each kind of European sword, halberd, armor, spear, and shield, has their Chinese names, easily avoiding many misunderstandings. It reflects a kind of information asymmetries and causes many difficulties when doing research.

The research on the cavalry of the Song Dynasty was not so difficult. Because two senior officials of the Song Dynasty named Zeng Gongliang (999-1087) and Ding Du (990-1053) once wrote a famous military work called Wujingzongyao, describing the weapons and armors of the soldiers of the Song Dynasty in extraordinary detail [3]. The equipment introduced in 
this paper was mostly based on the records of these two scholars. The research on the armors of the Liao Dynasty was much more difficult. Unlike in Europe, it was illegal to use armors as personal collection or funerary objects in the Liao Dynasty. Therefore, the only unearthed relics were some helmets and lamellar armor. In such a situation, mural paintings and sculptures were valuable researching resources. Fortunately, some historians and painters had reproduced the appearance of these armors.

In order to make the results of the comparative study relatively rigorous, the time of the research should be limited from 976 A.D to 1005 A.D., because during this time, both Liao and Song attached great importance to their cavalry, and the battles were representative. After concluding the peace treaty in 1005 A.D, the cavalry of these to empire started to go downhill.

This paper's purpose was to draw a conclusion that the cavalry of which dynasty was more powerful through analyzing the equipment, tactics, and performance in the battlefield of the cavalry of these two dynasties.

\section{HISTORICAL BACKGROUND}

\subsection{The revival of Chinese heavy cavalry}

Liao, Song, Xia, and Jin Dynasties were the revival of Chinese heavy cavalry. The heavy cavalry was popular in the Northern and southern Dynasties. At that time, both the soldiers and their horses would wear heavy armor. In Chinese, such kind of cavalry was usually called "Jiaqijuzhuang", translating literally as " armed cavalry ". According to The history of Song Dynasty (1345), the official history records of the Song Dynasty, "Jiaqi" was the armor of the soldier and "Juzhuang" was the armor of the horse [4]. In the Northern and southern Dynasties, this kind of cavalry usually wore iron armor and was equipped with a sword and a lance, as shown in Figure 1.

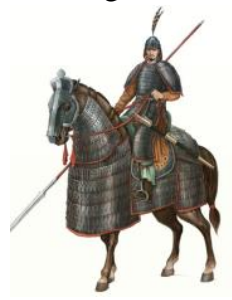

Figure 1 The Jiaqijuzhuang in the Northern and southern Dynasty [5].

In order to make the concept of "Jiaqijuzhuang" more clear, some famous cavalries are used to illustrate an abstract.
The image of Mongolian heavy cavalry was shown in Figure 2. Both the soldier and his horse were equipped with armors, which means they accorded with the concept of "Jiaqijuzhuang" or "Armed cavalry".

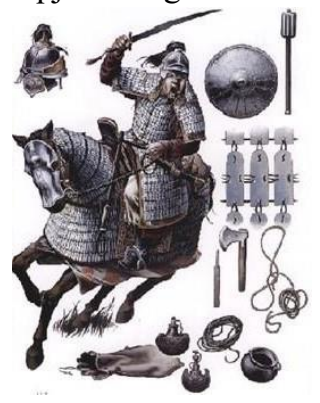

Figure 2 Mongolian heavycavalry [6] .

The image of Gothic heavy cavalry was shown in Figure 3. We could notice that only the soldier wore armor. Though he was a heavy cavalry, he couldn't be called "Jiaqijuzhuang".

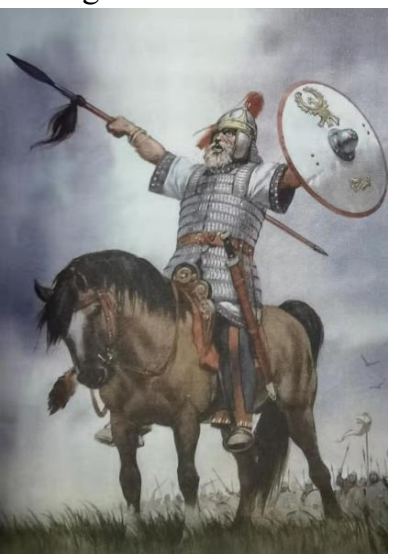

Figure 3 Gothic heavy cavalry [6].

In Chinese, after coming to the Tang Dynasty, the nomads became the main enemy of the central empire. Therefore, the heavy cavalry of the Tang Dynasty gave up the armors of horses to increase mobility [7]. After the Tang Dynasty's collapse, many small regimes built by different warlords kept fighting for a long time. This time was called the Five-dynasty Period. Finally, a famous general named Zhao Kuangyin (927-976) became the final winner and built the Song Dynasty in 976 A.D. After annexing all the small countries in the south of China, the Song Dynasty started to fight against the largest empire in North Asia-the Liao Dynasty built by the Khitans.

In the Five-dynasty Period, the armed cavalry appeared on the battlefield again. Because each country was quite near, the horsemen didn't need to have longrange raids, and those armors on horses became their favourite equipment again. The Khitans, the Liao Dynasty builder, also organized their own armed cavalry after several wars with these small regimes. Naturally, when the war between Liao and Song started, 
the scene of heavy cavalry's charging appeared frequently.

In the Liao, Song, Xia and Jin Dynasties, the fight of the heavy cavalry was throughout the whole time [8]. These four regimes pay much attention to their heavy cavalry. Many new types of armors and weapons appeared and were widely used in these times. These heavy cavalry units also had many unique names, such as Iron Forest Army (the Liao Dynasty), Iron Sparrowhawk Army (the Liao Dynasty and the Western Xia Regime), Silent Fortress Army (the Song Dynasty) and Iron Tower Army(the Jin Dynasty). These armies stood for the highest level of East Asian heavy cavalry and owned the best equipment in the world.

However, when heavy cavalry was on a rampage, the light cavalry still had their roles. Especially for the Liao Dynasty, light cavalry was the main force of the army. Because of that, when facing the heavy cavalry of the Song Dynasty, especially the Silent Fortress Army, Khitan cavalry usually lost.

\subsection{The peak of Chinese lamellar armor}

Chinese armors owned its unique system. In this system, lamellar armors where the predominant type until the firearms were widely used. Before the firearm culture time, though ancient Chinese soldiers sometimes were also equipped with mails or scale armors, lamellar armor's position could never be taken place.

The Song Dynasty was the peak of Chinese lamellar armor. The most noteworthy feature of the armors of these times was they were really heavy.

From the records in 1168 A.D, the lightest kind of infantry armors equipped by the crossbowmen of Song was over 22.2 kilograms. At the same time, the mails equipped by most of the European soldiers were only 13 kilograms. Using such kind of heavy armors was a kind of attempt to help the infantry resist the heavy cavalry because the weapons of heavy cavalry were greatly changed. We could even say that the heavy cavalry of that time gave birth to the extra heavy lamellar armors of the Song Dynasty.

From the armors of the infantry, we could see how powerful the heavy cavalry of that time was. For the infantry, just wearing heavy armor was not enough to defeat these horsemen. In the Tang Dynasty, Modao (as shown in Figure 4, the weapon used by the warrior) was widely used by the infantry to fight against the cavalry. When coming to the Song Dynasty, Modao was not enough to break the armors of the cavalry, and the infantry started to use heavier weapons such as poleaxes (as shown in Figure 5 and 6). From this change, we could easily see that cavalry's armors had got great impress compared with those dynasties before.

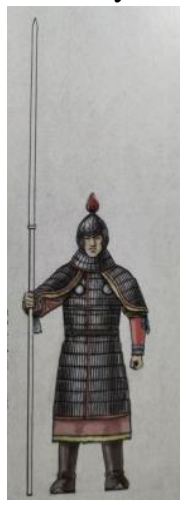

Figure 4 A warrior of the Tang Dynasty [9].

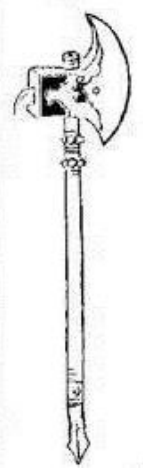

Figure 5 The poleaxe of the Song Dynasty [3].

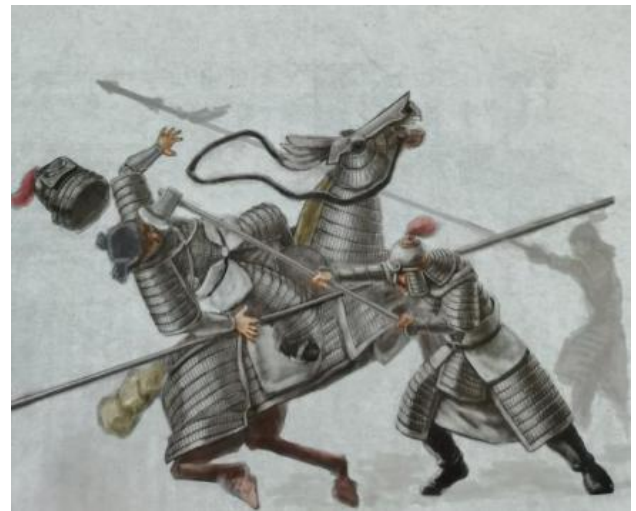

Figure 6 An infantry defeated a heavy cavalry with his poleaxe [9].

\section{THE MILITARY SYSTEM AND EQUIPMENT OF THE CAVALRY OF THE LIAO DYNASTY AND THE SONG DYNASTY}

\subsection{The military system of the cavalry of the Liao Dynasty}

The Khitans were nomads, and the structure of their army was a little similar to those of the Huns and Mongolian. The light cavalry was the main force of the 
army. However, comparing with the Huns, the army of both Khitan and Mongol own heavier cavalry.

The Liao Dynasty totally owned three hundred thousand soldiers in its army [10]. According to The history of Liao Dynasty, the imperial guards were called Pishi Army and Shushan Army [11]. Pishi Army consisted of thirty thousand cavalries and Shushan Army consisted of twenty thousand cavalries [10]. They were the most important force in the system of the Liao army.

A typical Khitan army usually consisted of over thirty thousand cavalries. Three thousand cavalrirs would be picked out to act as a vanguard. One hundred warriors would be chosen as scouts. The people in the army can be divided into two groups: soldiers and attendants. Soldiers were the main force of the army. A soldier usually owned three horses. Each soldier could command two attendants. The missions of the attendants were to defend their materials and pillage from the civilians of hostile countries [11].

When fighting, those horse archers without armors would be put in the front of the military array. Lancers would follow the horse archers. "Jiaqijuzhuang" or we called armed cavalry, would be on the last of the array. They usually would be in reserve.

\subsection{The equipment of the cavalry of the Liao Dynasty}

\subsubsection{Weapons}

The most common weapons used by the cavalry of the Liao Dynasty were composite bows. Except for the light cavalry, some Khitan heavy cavalry would also be equipped with bows. Song Qi (917-996), a senior official of the Song Dynasty once summarized the characteristic of Khitan cavalry: good at using bows, bad at using swords and halberds. According to Songqi's Pingyanjishice, bad at using swords and halberds was the conclusion comparing with the army with the soldiers from the Central Plains. It proved that bows were exactly the most widely used weapons in the army of the Liao Dynasty.

For the heavy cavalry, lances were the polearms they used most. The military technology of the Khitans was learned from the Tang Dynasty, both the weapons and the armors. So there was nothing strange that their weapons are similar to that of the Tang Dynasty. Figure 7 shows the image of the heavy cavalry of the Tang Dynasty, and Figure 8 shows the appearance of Khitan heavy cavalry. Without the hairstyle, it would be hard to distinguish.

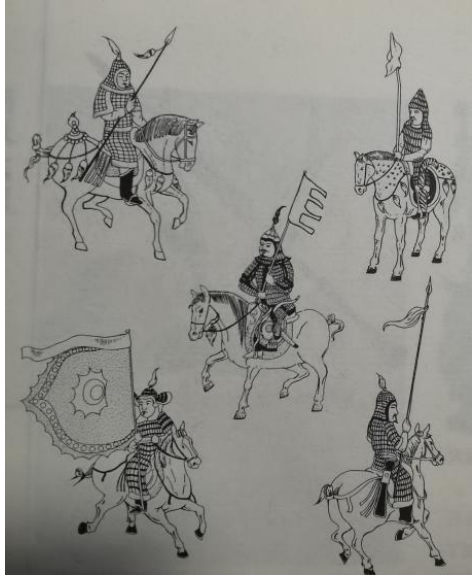

Figure 7 The heavy cavalry of the Tang Dynasty [6].

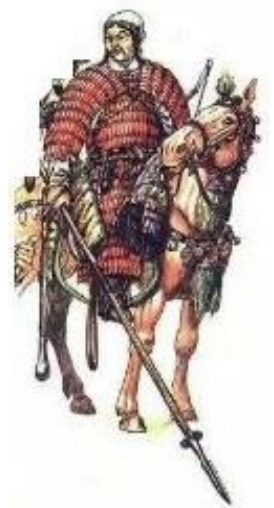

Figure 8 The heavy cavalry of the Liao Dynasty [6].

However, the secondary weapons of the Khitan heavy cavalry were different from that of the Tang Dynasty's. With the development of the armors, the swords used by cavalry were not enough to hurt their enemies. As a result, an old type of short weapons-war mace was widely used by the Chinese cavalry in the $10^{\text {th }}$ century. Actually, in the whole Liao, Song, Xia and Jin Dynasties, the blunt weapons always of great importance proved how excellent the Chinese armors of that time were.

\subsubsection{Armors}

Influenced by some novels, TV dramas, and movies, many people thought that the image of the Khitan warriors was wearing a leather hat and wearing leather armor, which were quite similar to the image of the Huns. However, the truth is the clothing of the warriors of the Liao Dynasty was mostly the same as that of the Tang and Song Dynasty, usually including iron helmet and lamellar armor [12]. The typical image of the warrior of the Liao Dynasty was as shown in Figure 9. 


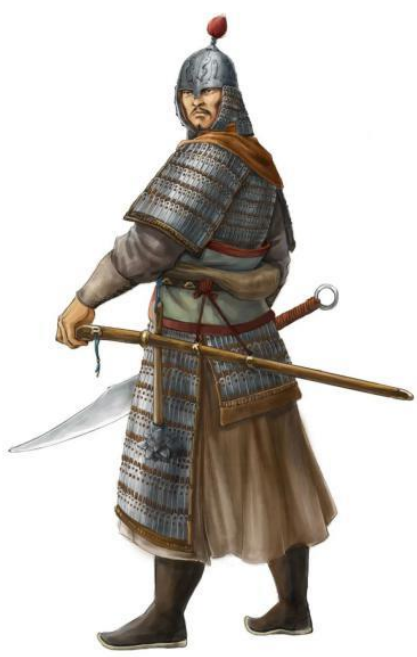

Figure 9 A warrior of the Liao Dynasty [5].

As we had said before, it was illegal to keep armors as a personal collection. Therefore, the only relics were some helmets and a lamellar armor. What's worse, the records of the armors of the Liao Dynasty were too little. The only way to study the armors of the Liao Dynasty was through some paintings and sculptures. Experts also restored the armors through these paintings and sculptures [13]. The process of wearing the lamellar armor of the Liao dynasty was as shown in Figure 10.

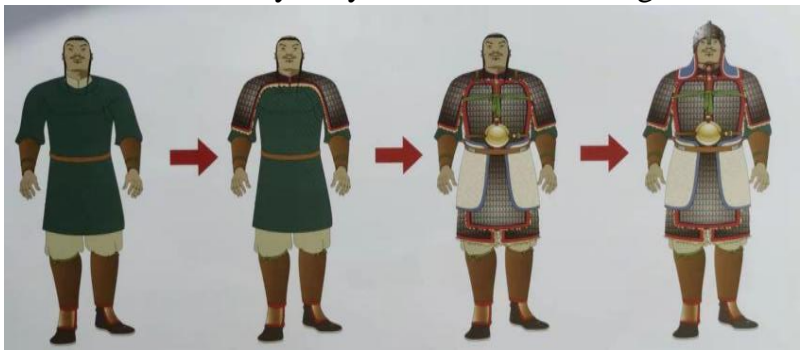

Figure 10 The process of wearing the lamellar armor of the Liao dynasty [13].

\subsection{The military system of the cavalry of the Song Dynasty}

\subsubsection{The brief introduction of the main force of the Song Dynasty}

Compared with the former Chinese dynasties, the Song Dynasty's military system was a totally new one. Since the first emperor of the Song Dynasty used to be a warlord, he paid much attention to limiting those generals' power after he became the emperor. One of his measures was to strengthen the central army and greatly weaken the regional troops. Fortunately, under the warlord emperor's leadership, the early Song Dynasty's army kept getting a victory in the war with the Khitans. However, after the old emperor passing by, those new ones didn't have the same ability, and the war with the Liao Dynasty was soon under the cosh.

The army of the Song Dynasty was divided into four groups: imperial guards, garrison troops, village soldiers, and Fanbing army [10]. The imperial guards were the central army, and the other three were the regional troops. The imperial guards were the main force of the army and fought most of the battles. The garrison troops belonged to each city and needed to assist the imperial guards. The village soldiers were civilian's spontaneous military communities. The Fanbing army was consisted of soldiers from the northeastern minority nationality. About one fifth of them served as cavalries [14].

Most of the cavalry of the Song Dynasty was affiliated with the imperial guards. Most of the cavalry that fought against the Khitans had an affiliation to Hebei imperial guards and Northwestern imperial guards. The Hebei imperial guards originated from the army of emperor Zhao Kuangyin and his subordinates which were the main force in the early Song Dynasty. The Northwestern imperial guards belonged to those warlord families who garrisoned in the northwest frontier. Some warlord families, such as the famous She's Family, even stayed in the northwestern area for more than a hundred years. In order to control them, the emperors usually sent their confidants to the frontier, monitoring and leading these warlords.

During the war between Liao and Song, the Hebei and Northwestern imperial guards maintained good cooperation and efficient fighting force. However, after the war came to an end, the Hebei imperial guards quickly went downhill because they had been at peace for so long. The Northwestern imperial guards then devoted themselves to the Xia Regime and kept their fighting force until the end of the Northern Song Dynasty.

\subsubsection{The development of the cavalry of the Song Dynasty}

The development of the cavalry of Song army should be divided into two period: a short peak and a long valley. After the war with the Khitans, most of the cavalry of the Song Dynasty kept going downhill. The number of horses started to fall and the training of soldiers began to be neglected. The only revival was the times of general Yue Fei (1103-1142).

In the beginning, the cavalry of the Song Dynasty could be seen as really powerful because they were the veterans surviving the cruel wars of the Five-dynasty Period. However, most of them sacrificed on the battlefield of Youzhou. Some regional troops, such as the famous Silent Fortress Army, became the new 
central army. Under the leadership of some famous generals such as Cui Yanjin (922-988) and Li Jilong (950-1005), the newly built main force got some victories during the war. They even defeated the imperial guards of the Liao Dynasty several times [4].

After the war with the Khitans, most of the cavalry quickly lost their fighting force except those cavalries of the Northwestern imperial guards. At the same time, the training of cavalry started to go in the wrong direction. Under the influence of the Khitans, riding and shooting took most of their time, and the skills of using swords and lances were ignored [15]. It would give these cavalries a tough lesson in the next war.

\subsection{The equipment of the cavalry of the Song Dynasty}

\subsubsection{The weapons}

Both in the Eastern and in the Western, lance was the best friend of the cavalry. In the Song Dynasty, lance was widely used and developed its unique shapes. These strange lances were all called halberds by western scholars. Wujingzongyao(1044) recorded some types of lances. Their images were as shown in Figure 11.

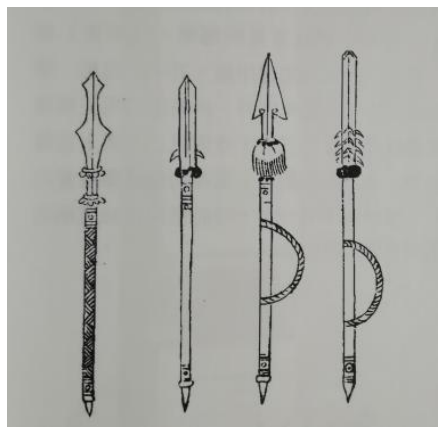

Figure 11 The lances of the Song Dynasty [3].

Comparing with the lance before, some lances of the Song Dynasty added a loop on the handles. When they did not need to fight, soldiers could put their lance on their shoulders, which is a humanized design.

We could also notice that there were some barbs on the spearhead. There was a popular tactical action called seizing the lance (as shown in Figure 12). These barbs could make the tactical action become more difficult [3].

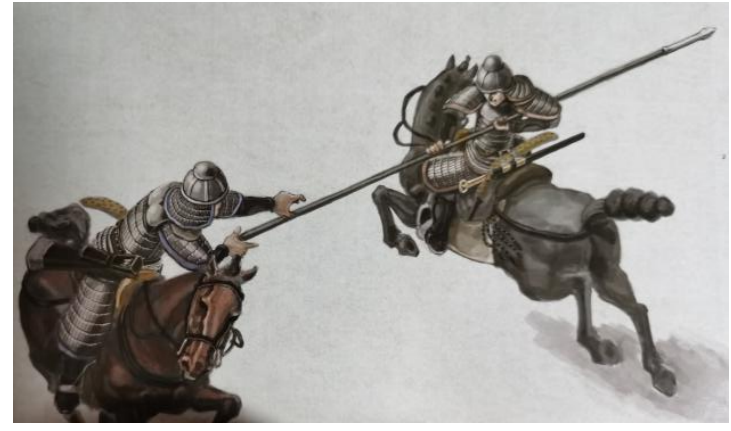

Figure 12 Seizing the lance [9].

As mentioned before, the armors of the Song Dynasty were really heavy and hard to break. The weapons of the cavalry also made some changes to suit the needs.

Firstly, the long-handled swords (as shown in Figure 13) became the main weapon. This kind of sword first appeared in the Tang Dynasty, and the infantry always used it to fight against cavalry. In the Song Dynasty, such a sword got a longer handle and more suitable for the cavalry. The Ming Dynasty's generals recorded its skills, and we still had a chance to learn them. In a famous Chinese novel, The Romance of the Three Kingdoms (the early Ming Dynasty), the famous general Guan Yu also used such a weapon.

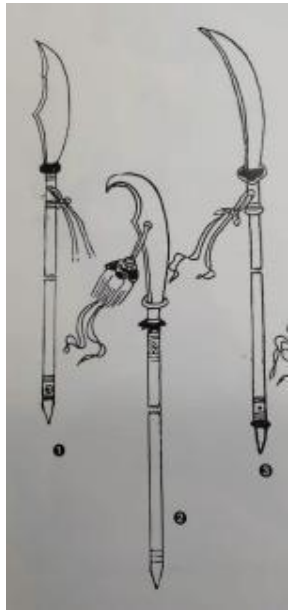

Figure 13 The long-handled swords of the Song Dynasty [3].

Secondly, the secondary weapons of the cavalry also changed. As mentioned before, common swords were of no use when facing the heavy armors of that time, so except the maces, the Song Dynasty's cavalry also started to use a kind of heavy weapon-sword breaker. It looked like a sword, but the sword blade was taken place by an iron club. According to the official records, many generals of that time were good at using sword breakers. Here we extract some records from The history of Song Dynasty. "Ren Fu waved his sword breaker and fought bravely. At last, his left cheek and neck were penetrated by a spear, and he finally died" 
[4]. Also taken from The history of Song Dynasty, "(the army of the Song Dynasty) meeting the army of the Xia regime and one of the horsemen starting to provoking, Zhang Yu rushed out from the array of the Song army with his sword breaker, killing the horseman and seizing his horse" [4]. Actually, according to The history of the Jin Dynasty (1344) and The history of Song Dynasty, the sword breaker was hard to use if it did not have enough training because of its weight. Therefore, it was always used by those generals and strong warriors [4, 16]. More importantly, the sword breaker was a badge of identity and a symbol of justice in ancient China. Therefore, some civil officers also owned a sword breaker. For example, prime minister Li Gang (10831140) owned a sword breaker, and the relic was still in the museum of Fujian Province (as shown in Figure 14).

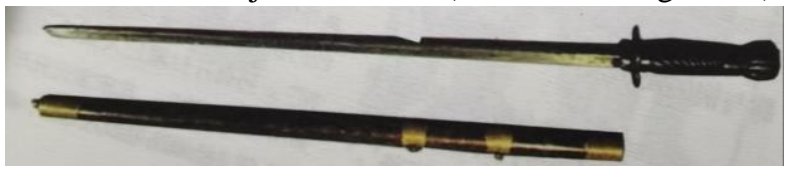

Figure 14 Li Gang's sword breaker [9].

\subsubsection{The armors}

The classical image of the cavalry of the Song Dynasty was as shown in Figure 15.

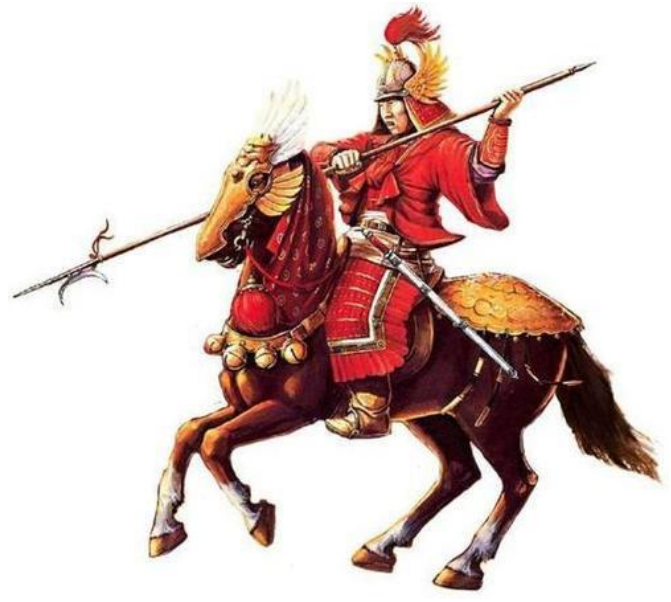

Figure 15 A cavalry of the Song Dynasty [6].

From the foofaraw of his helmet, we could easily make sure that he was an officer. The image of the common soldier was as shown in Figure 16. The helmet decorated with the wings of the phoenix was the most famous image of an ancient Chinese warrior. Such type of helmet first appeared in the late Tang Dynasty and became popular in the Song and Ming Dynasties. Wujingzongyao also recorded it (as shown in Figure 17).

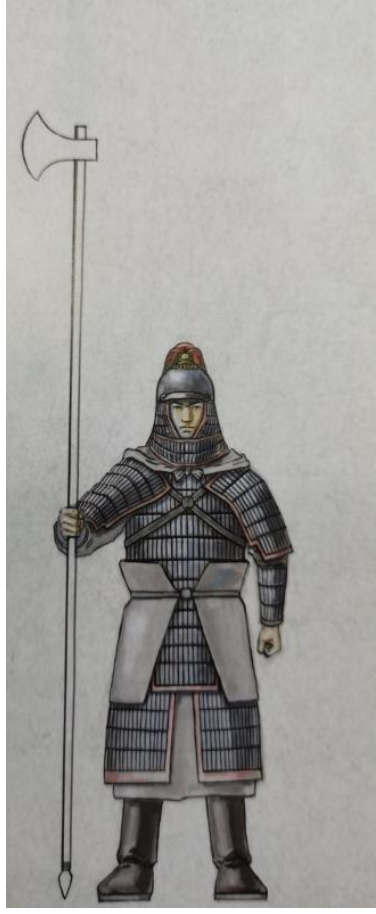

Figure 16 A warrior of the Song Dynasty [9].

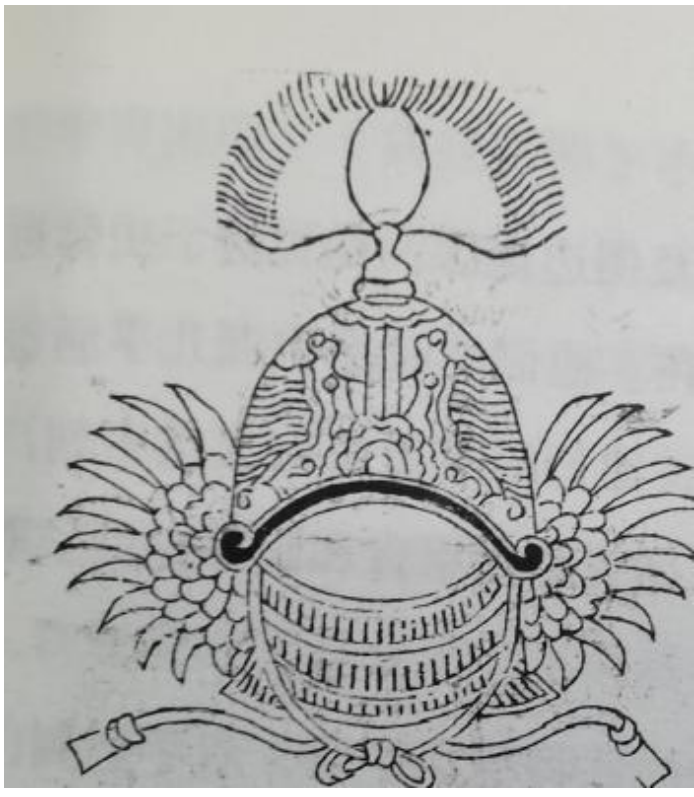

Figure 17 A helmet of the Song Dynasty [3].

The shapes of the armors of the Song Dynasty were clearly described in Wujingzongyao. The book even offered a picture of these armors, which could help us better restored them. The picture was as shown in Figure 18. At that time, the heavy cavalry and infantry of the Song Dynasty were equipped with these armors and fought against the enemies from the north and northwest. Comparing with the Khitans cavalry, the armors were an important advantage that the cavalry of the Song Dynasty had. 


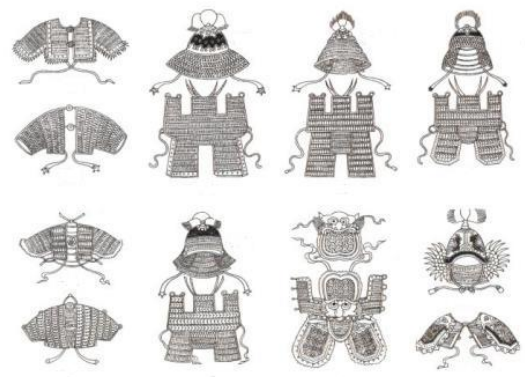

Figure 18 The armors recorded in Wujingzongyao [17].

However, unfortunately, Wujingzongyao did not point out which armors belonged to the cavalry. We just could make sure of the shape of the famous infantry armors (as shown in figure 19). Its wearing effect was as shown in Figure 18.

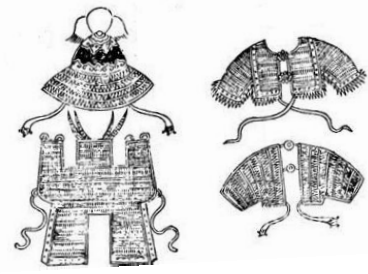

Figure 19 The infantry armor of the Song Dynasty [3].

Fortunately, from a famous painting of the early Song Dynasty (as shown in Figure 20), we could see the heavy cavalry's image of that time. His armor was the same as one of the armors in Wujingzongyao, but added some decorations. This type of armor was also commonly appeared on the sculptures of that time.

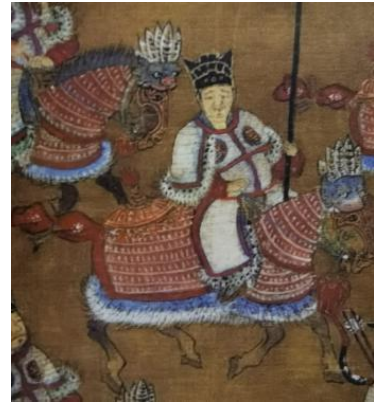

Figure 20 The heavy cavalry of early Song Dynasty [6].

Except for the armors of the soldiers, the horses were also equipped with armors (as shown in Figure 21). Not only the paintings but also Wujingzongyao had detailed descriptions of the armors of horses. Unlike those of the Northern and southern Dynasties, most of the armor of horses in the Song Dynasty was made of leather [3]. It was a balance between protection and motility. After all, the Khitans' main force was light cavalry, and leather armors could provide the horses with enough protection when facing the bows used by horsemen. So, there was no necessity to decrease the motility with iron horse armors.

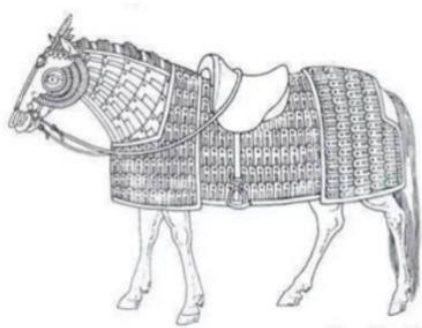

Figure 21 The horse armor of the Song Dynasty [17].

\section{THE CLASSICAL BATTLES BETWEEN THE CAVALRY OF THE LIAO AND SONG DYNASTIES}

\subsection{History background}

Before the Song Dynasty, the Khitans had fought against those small regimes for decades, with ups and downs on both sides. After a few battles with the Latter Zhou Dynasty, the Khitans lost the initiative. After the Song Dynasty was built, the Liao Dynasty lost every battle when facing emperor Zhao Kuangyin and his powerful army. After Zhao passing away, the Khitans started to win the initiative back. However, the commanders of both sides found that their ability was enough to defend but could not support an active attack. Then, these two empires had a series of seesaw battles for nineteen years (the whole war lasted for twenty-five years).

In this process, there were three battles that could help us learn and analyze the tactics and battlefield performance of the two empires' cavalry. The process and analysis would be shown below.

\subsection{The Yongxi's Northern Expedition (986 A.D)}

\subsubsection{The situation of both sides}

The situation of both sides was as shown in Table 1 . Table 1. The general situation of the Yongxi's Northern Expedition

\begin{tabular}{|l|l|l|}
\hline Regime & $\begin{array}{l}\text { The Liao } \\
\text { Dynasty }\end{array}$ & The Song Dynasty \\
\hline Commanders & $\begin{array}{l}\text { Yelv Xiuge } \\
\text { and Yelv } \\
\text { Xiezhen }\end{array}$ & $\begin{array}{l}\text { Cao Bin, Cui Yanjin and Li Jilong(the } \\
\text { east route army, main force) } \\
\text { Tian Zhongjin(the middle route army) } \\
\text { Pan Mei and Yang Ye(the west route } \\
\text { army) }\end{array}$ \\
\hline $\begin{array}{l}\text { The quantity of } \\
\text { soldiers }\end{array}$ & $\begin{array}{l}\text { About } \\
200,000\end{array}$ & About 200,000 \\
\hline Result & Victory & $\begin{array}{l}\text { The east route army suffer a humiliating } \\
\text { defeat. } \\
\text { The middle route army retrearted. } \\
\text { The west route army retreated and lost } \\
\text { the troops behind. }\end{array}$ \\
\hline
\end{tabular}




\subsubsection{The process of the battle}

In March of 986 A.D, three armies of the Song Dynasty started to carried into the territory of the Liao Dynasty. Two generals from the royal family- Yelv Xiuge (?-998) and Yelv Xiezhen (?-999) were appointed as the Liao army commanders. First defeated the middle route army with superior force. Then, they started to assault the logistics units of the east route army with their light cavalry. After two months, the east route army had been no food for some time, and the morale had exhausted. The main force of the Khitans started to attack, and the east route army was nearly wiped out. The commanders of the east route army just escaped with some cavalry. Finally, the Khitans started to attack the west route army with superior force and killed Yang Ye, one of the most famous generals of the Song army. The rest of the west route army had to retreat.

\subsubsection{The analysis of the battle}

In this battle, the Khitan light cavalry played an important role or we could say that the flexible use of light cavalry was the most important reason that the Khitans got the final victory.

Firstly, the main force of the Song army was infantry and did not have enough mobility. A large amount of light cavalry allowed the Khitans could always keep numerical superiority on each battlefield. Because of the high mobility, they could concentrate forces and defeat the Song Dynasty's armies one by one. Concentrating superior forces and adapting outflanking tactic was the classic tactic that used by Yelv Xiuge. More than a hundred years later, such kind of tactic was also widely used by Mongolians.

More importantly, Yelv Xiuge also paid attention to cutting the supply lines. Compared with ancient Japan or Europe, the ancient Chinese army's supply lines were much longer because of the large territory. Therefore, the commanders of ancient China were really in favor of the tactic of cutting the supply lines. The best troops to do this was the light cavalry because they were the raid and mobile war experts. Take the east route army of the Song dynasty as an example. They set out from Bianliang city (today's Kaifeng city in Henan province), and their aim was Youzhou city (in the west of Beijing). In modern times we even need to drive for more than six hours. In the times of the Song Dynasty, the time of march was more than two months which gave the Khitan light cavalry many opportunities to cut the supply lines. In fact, Yelv Xiuge just did it and easily defeated the east route army.

This battle was the transition of the war. After this battle, the Khitans got back the initiative and started to take more active actions.
4.3. The Battle of the Tanghe River Area $(988$ A.D)

\subsubsection{The Situation of Both Sides}

The situation of both sides was as shown in Table 2 .

Table 2. The general situation of the Battle of the Tanghe River Area

\begin{tabular}{|l|l|l|}
\hline Regime & The Liao Dynasty & The Song Dynasty \\
\hline Commanders & $\begin{array}{l}\text { Yelv Longxu(the } \\
\text { emperor of the } \\
\text { Liao Dynasty) and } \\
\text { Yelv Xiuge }\end{array}$ & $\begin{array}{l}\text { Li Ji Long, Guo } \\
\text { Shouwen, Yuan Jizhong } \\
\text { and Tian Min (the } \\
\text { commander of the Silent } \\
\text { Fortress Army) }\end{array}$ \\
\hline $\begin{array}{l}\text { The Quantity of } \\
\text { soldiers }\end{array}$ & 80,000 & $\begin{array}{l}10,000 \text { (including Silent } \\
\text { Fortress Army) }\end{array}$ \\
\hline Result & Defeated & Victory \\
\hline
\end{tabular}

\subsubsection{The process of the battle}

The Khitans cavalry commanded by Yelv Longxu (972-1031) started to attack the Song Dynasty cities in September of 988 A.D. After defeated by Zhang Qixian(942-1014), the Khitans changed the direction and marched to the Tanghe River Area. They were defeated by the local army commanded by Guo Shouwen (935-989). However, the quantity of the army of the Song Dynasty was too few, and they had to have a confrontation with the Khitans. A few days later, the cavalry of the Song Dynasty commanded by Li Jilong (950-1005), and Yuan Jizhong (938-992) started to attack the Khitans. The Silent Fortress Army charged and opened a gap on the array of the Khitans. Then the army of the Khitans was invaded and encased. They had to retreat to the Caohe River area.

\subsubsection{The analysis of the battle}

In this battle, Li Jilong made full use of the Silent Fortress Army. These armed cavalries were from Yizhou city and fought against the Khitans for a long time. Each soldier kept five horses, and both the soldiers and their horses were equipped with armors. In the war with the Khitans, the Silent Fortress Army won every battle they took part in. Excepting the bows, all of the soldiers were good at using a lance. They were commanded by one of the most famous cavalry commanders of the Song Dynasty-Tian Min. In the battle, Tian Min commanded his cavalry to open a gap on the array of the Khitans and got the victory [4].

For the Khitans, this battle exposes a great problem for their army. The light cavalry in the army was too much, which led to the deficiency of defending. When facing the charging of heavy cavalry in the frontline battlefield, they even could not keep the formation. This 
problem would accompany the Khitans until the end of the Liao Dynasty.

\subsection{The battle of Weilujun City (1001 A.D)}

\subsubsection{The situation of both sides}

The situation of both sides was as shown in Table 3 . Table 3. The general situation of the battle of Weilujun City

\begin{tabular}{|l|l|l|}
\hline Regime & The Liao Dynasty & The Song Dynasty \\
\hline Commanders & $\begin{array}{l}\text { Yelv Longqing(the brother of the } \\
\text { emperor) }\end{array}$ & $\begin{array}{l}\text { Wei Neng, Qin Han, } \\
\text { Tian Min, Yang } \\
\text { Yanzhao, Yang Si } \\
\text { and Li Jixuan }\end{array}$ \\
\hline $\begin{array}{l}\text { The Quantity of } \\
\text { Soldiers }\end{array}$ & $\begin{array}{l}\text { Fo,000cavalry(including Iron } \\
\text { Forest Army) }\end{array}$ & 35,000 cavalry \\
\hline Result & $\begin{array}{l}\text { Defeated } \\
\text { The whole Iron Forest Army was } \\
\text { wiped out }\end{array}$ & Victory \\
\hline
\end{tabular}

\subsubsection{The process of the battle}

In November 1001 A.D, the Khitans cavalry started to invade the territory of the Song Dynasty. Some cavalry of the Song army lured the main force of the Khitans to the Weilujun city defended by the six generals named Wei Neng (?-1015), Qin Han(9521015), Tian Min(the year of birth and death was unknown), Yang Yanzhao(958-1014), Yang Si(9341014) and Li Jixuan(950-1013) and their elite cavalry. The Khitans were first defeated by Wei Neng, Qin Han, and Tian Min on the frontline battlefield. The army of Wei Neng wiped out the whole Iron Forest Army. Then, the cavalry of Qin Han and Tian Min began to pursue the retreating Khitans. After escaping to the Yang Mountain, the Khitans were intercepted by the cavalry of Yang Yanzhao and Yang Si. After a brief fight, the Khitans started to ran away again and finally caught up by Li Jixuan. However, general Li did not have enough troops to annihilate them. The Khitans finally escaped.

\subsubsection{The analysis of the battle}

In this battle, we can clearly see that compared with the Song Dynasty's cavalry, the cavalry of the Liao Dynasty extremely lacked the ability to fight on the frontal battlefield. Even had the great advantage of quantity, they still could not make any gap on the lines of the Song army. On the contrary, even the elite cavalry Iron Forest Army could not show their own power. Without a long time, their commander was killed by Wei Neng. Then the line of the Iron Forest Army started to come to a mess, and the morale of the Khitans began to be exhausted.

After the death of Yelv Xiuge, the Liao Dynasty started to get a series of failures in a military area. The commanders of Khitans gave up the outflanking tactics and always tried to defeat Song and Xixia Regimes on the frontal battlefield. However, their nomads-style army did not suitable for such kind of high-intensity confrontations. After giving up the advantage of high motility, the only result of the light cavalry was eliminated. For the Khitan heavy cavalry, their armors were not as good as those of the Song Dynasty's heavy cavalry, which caused their disadvantage when charging.

\section{CONCLUSION}

There's no doubt that the light cavalry of the Liao Dynasty was more excellent. With the lead of good commanders, their flexible tactics and high mobility could get an unexpected effect. It was an advantage that the cavalry of the Song Dynasty did not have.

However, in the heavy cavalry field, it was clear that the Song Dynasty was better. The advantage came from the gap in technology. Comparing with the common lancers, the "Jiaqijuzhuang" or armed cavalry surely had a great advantage in close combat. That was the correct tactic for the cavalry of the farming peoples when facing the nomads. Evidently, during the war between the Liao and Song Dynasties, the cavalry of the Song Dynasty was not that bad as the stereotype described. They successfully used the advantages of technology such as armors and weapons to offset the disadvantage of quantity. Judging from the equipment and performance, the Song Dynasty's cavalry during the war between Liao and Song could be seen as one of the most powerful cavalries in the world.

\section{REFERENCES}

[1] Wei Shou, Wei Shu[The history of the Northern Wei Dynasty]., Zhonghua Book Company, Beijing, 1974.

[2] Qian Mu, Outline of Chinese History, Commercial Press, Beijing, 1996.

[3] Zeng Gongliang., Ding Du, Wujingzongyao[The tactics and weapons of the Song Dynasty]., Commercial Press, Beijing, 2017.

[4] Tuotuo, The history of Song Dynasty., Zhonghua Book Company, Beijing, 1985.

[5] Zhou Yu, Illustrated handbook of the history of Chinese armor., Jiangsu Phoenix Literature and Art Publishing, Nanjing, 2020. 
[6] Longyuzhe, Thousand years war history of heavy cavalry., Jilin literature and history Publishing House, Changchun, 2017.

[7] Jia Wei, An analysis of the historical changes of ancient Chinese armors. Master, Tianjin Normal University, Tianjin, June 2010.

[8] Wu Guoqing, The Chinese war history., People's Publishing House, Beijing, 2016.

[9] Zhiwen Fenghuo studio, Illustrated handbook of ancient Chinese weapons, Jilin literature and history Publishing House, Changchun, 2018.

[10] War theory and Strategy Research Department of Academy of Military Sciences, Classic battles in ancient China., PLA Press, Beijing, 2012.

[11] Tuotuo, The history of Liao Dynasty., Zhonghua Book Company, Beijing, 1974.

[12] Cong Milin, Research on the Khitan cavalry. Master, Northeast Normal University, Changchun, May 2018.

[13] Chen Dawei, Illustrate Ancient Chinese Armour., Chemical Industry Publishing House, Beijing, 2017.

[14] Xia Yafei, Study on the cavalry of the Song Dynasty. Master, Henan University, Kaifeng, May 2013.

[15] Li Tao, Continuation of Zizhi Tongjian., Zhonghua Book Company, Beijing, 2004.

[16] Tuotuo, The history of the Jin Dynasty., Zhonghua Book Company, Beijing, 1975.

[17] Zheng Zhenduo, Ancient Chinese prints., Shanghai ancient books Publishing House, Shanghai, 1988. 